\title{
Individual cell growth rates of marine bacteria, measured by bromodeoxyuridine incorporation
}

\author{
Koji Hamasaki ${ }^{1,2, *}$, Richard A. Long ${ }^{1,3}$, Farooq Azam ${ }^{1}$ \\ ${ }^{1}$ Scripps Institution of Oceanography, University of California, San Diego, La Jolla, California 92093-0202, USA \\ ${ }^{2}$ Present address: Graduate School of Biosphere Science, Hiroshima University, Higashi-Hiroshima, \\ Hiroshima 739-8528, Japan \\ ${ }^{3}$ Present address: Department of Oceanography, Texas A\&M University, College Station, Texas 77843-3146, USA
}

\begin{abstract}
We tested the application of 5-bromo-2'-deoxyuridine (BrdU), a thymidine analogue that becomes incorporated into DNA during growth, to measure growth rates of individual marine bacteria cells. Immunocytochemical detection of BrdU incorporation into bacterial DNA has the potential for single-cell-based growth measurement. Optimized procedure for immunocytochemistry was applicable to 14 marine heterotrophic bacterial isolates belonging to $\gamma$-proteobacteria, $\alpha$-proteobacteria, Cytophaga-Flavobacterium-Bacteroides (CFB) group and Gram-positive bacteria. The relationship between cell-specific fluorescence intensity and specific growth rate was linearly correlated among CFB group isolates, which indicated a potential of the method for quantitative measurement. Analysis of the detection limit indicated that bacteria with $<1 \mathrm{~d}$ doubling time could be detected in $5 \mathrm{~h}$ incubations using bacterial assemblages in seawater. The method was also applied to visualize actively growing bacteria on phytoplankton detritus in seawater and was sensitive enough to test the variation in growth rate of natural bacterial assemblages in coastal waters using incubations of a few hours in duration. The method has the potential to yield insights into microspatial variability in bacterial growth rates in seawater.
\end{abstract}

KEY WORDS: 5-bromo-2'-deoxyuridine $\cdot$ Marine bacteria $\cdot$ Immunocytochemistry $\cdot$ Growth

\section{INTRODUCTION}

The importance of bacteria in organic matter fluxes in the ocean is now well recognized (Azam 1998, Kirchman \& Williams 2000). Biomass and production of bacteria measured in various oceanographic provinces indicate that bacteria are significant regulators of the fluxes of organic matter in the euphotic layers (Cole et al. 1988) and the mesopelagic zone (Cho \& Azam 1988). Also, culture-independent molecular techniques have revealed high diversity and dynamics in marine bacterial communities (e.g. DeLong et al. 1999, Cottrell \& Kirchman 2000a, Riemann et al. 2000, Fandino et al. 2001). While organic matter influences bacterial community structure, the dynamic changes in bacterial community composition and their microspatial activities can control organic matter fluxes, which emphasizes the necessity to study single-cellbased activities and growth with micro-scale resolution (Bidle \& Azam 1999, Azam \& Long 2001, Long \& Azam 2001a).

During the last 2 decades, many investigators have studied single-cell-based metabolic activities in natural assemblage of bacteria. Cell extension following treatment with DNA gyrase inhibitor nalidixic acid has been used to distinguish viable bacteria in natural samples (Kogure et al. 1979). Tetrazolium salt reduction to colored or fluorescent formazan precipitate within the bacterial cells has been used to examine the individual cell electron-transport system activity (Zimmermann et al. 1978, Rodrigues et al. 1992). Fluorescein diacetate and its analogues have been used to detect individual cell intercellular esterase activity (Tsuji et al. 1995). Growth rates at the individual cell 
level have been measured by microautoradiography using tritiated thymidine $\left({ }^{3} \mathrm{H}-\mathrm{TdR}\right)$ incorporation (Fuhrman \& Azam 1982, Douglas et al. 1987). However, the use of radioisotopes is often restricted by regulations, particularly in field settings. Ribosomal RNA content, estimated by fluorescent in situ hybridization using 16S rRNA oligonucleotide probes, has shown potential for measuring individual cell and speciesspecific growth rates, because rRNA:rDNA ratios are correlated with the growth rate of cultured marine bacteria (Kerkhof \& Ward 1993). However, the relationship is complex, and its applicability to natural assemblages of heterotrophic bacteria requires further development.

A promising non-radioisotopic approach is to use a thymidine analogue, 5-bromo-2'-deoxyuridine (BrdU). BrdU is not known to naturally occur in the environment, hence it is applicable to non-radioisotopic tracer incorporation studies. Further, it can readily be immunochemically detected with very high sensitivity. As in the case of microautoradiography, BrdU incorporation has the potential to provide microspatial information on bacterial growth in seawater. In cell biology, BrdU is widely used as an alternative to ${ }^{3} \mathrm{H}$-TdR incorporation to label proliferating cells (e.g. Van Furth \& Van Zwet 1988, Asquith et al. 2002). Recently, BrdU has been successfully used as an alternative to the ${ }^{3} \mathrm{H}$-TdR incorporation method in bulk measurements of bacterial production in seawater (Steward \& Azam 1999). Immunocapture of BrdU labeled DNA from soils and lake waters was applied to community structure analysis of metabolically active bacteria (Borneman 1999, Urbach et al.1999, Yin et al. 2000). Urbach et al. (1999) demonstrated immunocytochemical detection of BrdU incorporation into 2 marine bacterial isolates. The method was combined with fluorescence in situ hybridization using oligonucleotide rRNA-targeted probes and applied to bacterioplankton samples in coastal North Sea water (Pernthaler et al. 2002).

We have explored the possibility of developing a method to measure individual-cell growth rate applicable to a broad range of marine bacteria and natural marine assemblages. Specific aims of this study are to (1) optimize BrdU immunocytochemical staining so that it is applicable to a broad range of marine bacterial isolates, and (2) determine the method applicability for natural assemblages of bacteria in seawater.

\section{MATERIALS AND METHODS}

Reagents. Anti-BrdU monoclonal antibodies (Fab fragments from mouse), nucleases and incubation buffer were obtained as components of the BrdU Labeling and Detection Kit III from Boehringer-
Mannheim (currently available from Roche Molecular Biochemicals \#1444611). Although the exact formulation is not known because it is proprietary, the nucleases are known to contain exonuclease III and one or more restriction endonucleases (Dinjens et al. 1992, Steward \& Azam 1999). FITC-labeled streptavidine and TSA-Indirect Kit containing biotin-labeled tyramide, Amplification Buffer and Blocking Reagent were obtained from NEN Life Sciences (currently available from Perkin Elmer Life Sciences \#NEL700).

The SWM medium was prepared by amending GF/F filtered seawater with $0.0058 \%(\mathrm{w} / \mathrm{v})$ casamino acids, $0.69 \mathrm{mM}$ glucose, $0.30 \mathrm{mM} \mathrm{NH}_{4} \mathrm{Cl}, 0.25 \mathrm{mM} \mathrm{NaH}_{2} \mathrm{PO}_{4}$, $0.2 \mu \mathrm{M}$ ferric citrate and $0.2 \mu \mathrm{M}$ EDTA (G. Steward \& F. Azam unpubl.) and was modified by adding $0.001 \%$ $(\mathrm{w} / \mathrm{v})$ BACTO ${ }^{\mathrm{TM}}$ Peptone (Difco). The trace amount of peptone was added to stimulate growth, because some isolates did not grow well in the original SWM medium. Addition of BACTO ${ }^{\mathrm{TM}}$ Peptone causes contamination by thymidine at $18 \mathrm{nM}$ final concentration, estimated from the manufacture's data, but it may vary between lots. For this study, a single bottle of BAC$\mathrm{TO}^{\mathrm{TM}}$ Peptone was used for all media preparation. The formulation of other buffers and solutions are as follows: phosphate-buffered saline ( $\mathrm{PBS} ; 35 \mathrm{mM} \mathrm{NaCl}$, $2.7 \mathrm{mM} \mathrm{KCl}, 4.3 \mathrm{mM} \mathrm{NaH} \mathrm{PO}_{4} .7 \mathrm{H}_{2} \mathrm{O}$, and $1.4 \mathrm{mM}$ $\mathrm{KH}_{2} \mathrm{PO}_{4}$ [pH 7.0]), Tris-EDTA (100 mM Tris $\mathrm{Cl}$ and $50 \mathrm{mM}$ EDTA [pH 8.0]), TNT (100 mM Tris $\mathrm{HCl}[\mathrm{pH}$ 7.5], $150 \mathrm{mM} \mathrm{NaCl}$, and $0.05 \% \mathrm{v} / \mathrm{v}$ Tween 20), TNB (100 mM Tris Cl [pH 7.5], $150 \mathrm{mM} \mathrm{NaCl}$, and $0.5 \% \mathrm{w} / \mathrm{v}$ Blocking Reagent), anti-fading solution $(0.1 \% \mathrm{w} / \mathrm{v}$ ascorbic acid, 1:1 glycerol and PBS).

Labeling of marine bacterial isolates with BrdU. Marine bacteria used in this study were isolated and identified by partial sequences of the 16S rRNA gene in previous studies (Fandino et al. 2001, Long \& Azam 2001b). Bacterial isolates were grown in SWM medium at room temperature for 1 to $2 \mathrm{~d}$. An aliquot of each culture was inoculated into fresh SWM medium to obtain $\mathrm{OD}_{600}$ (optical density at $600 \mathrm{~nm}$ ) in the range of 0.01 to 0.02 . The experimental tubes $(10 \mathrm{ml})$ were supplemented with BrdU at $200 \mathrm{nM}$ final concentration. Bacterial cells cultured with $200 \mathrm{nM}$ TdR were also prepared for each isolate as negative controls to check non-specific signals. The cultures were incubated in the dark for $5 \mathrm{~h}$ at $23^{\circ} \mathrm{C}$ and then pelleted by centrifugation at $20000 \times g$ for $5 \mathrm{~min}$. For the slow-growing Isolate S-10, incubation was continued for $20 \mathrm{~h}$. The growth media was decanted, pelleted cells were fixed with $4 \%$ paraformaldehyde in PBS, washed with PBS and resuspended in PBS. The cell suspension was mixed with an equal volume of $100 \%$ ethanol and stored at $-15^{\circ} \mathrm{C}$.

Immunocytochemical detection of BrdU. Aliquots $(5 \mu \mathrm{l})$ of bacterial cell suspensions were spotted onto 
$6 \mathrm{~mm}$-diameter wells of Teflon printed glass slides (Electron Microscopy Science) and air-dried for $1 \mathrm{~h}$. The dried samples were dehydrated with serial treatment of 70,90 and $100 \%$ ethanol each for $3 \mathrm{~min}$. To quench endogenous peroxidase in the samples, the slides were treated with $3 \% \mathrm{H}_{2} \mathrm{O}_{2}$ in PBS for 10 min at room temperature and washed twice with PBS. They were then treated with $4 \%$ paraformaldehyde for $30 \mathrm{~min}$ at room temperature and washed 3 times with PBS. For permeabilization of bacterial cells, the slides were treated with $0.01 \mathrm{~N} \mathrm{HCl}$ for $5 \mathrm{~min}$ at room temperature, replaced with pepsin $\left(2 \mathrm{mg} \mathrm{ml}^{-1}\right.$ in $0.01 \mathrm{~N}$ $\mathrm{HCl}$ ) for $2 \mathrm{~h}$ at $37^{\circ} \mathrm{C}$, washed 3 times with PBS, treated with lysozyme (3 $\mathrm{mg} \mathrm{ml}^{-1}$ in TE buffer) for $15 \mathrm{~min}$ at room temperature and washed 3 times with PBS. Intracellular DNA was denatured by incubation with nucleases (1:100 in incubation buffer) for $2 \mathrm{~h}$ at $37^{\circ} \mathrm{C}$ and washed twice with PBS. Anti-BrdU monoclonal antibodies conjugated with peroxidase were diluted in PBS (1:500) containing 0.1\% BSA (bovine serum albumin), incubated with samples for $2 \mathrm{~h}$ at $37^{\circ} \mathrm{C}$ and washed 3 times with PBS. The antibody signal was amplified by catalyzed reporter deposition incubating the slides with a biotin-labeled tyramide diluted 1:50 in Amplification Buffer for $10 \mathrm{~min}$ at room temperature. After the wash with TNT buffer 3 times, the slides were treated with a FITC-labeled streptavidin in TNB buffer (1:500) for $30 \mathrm{~min}$ at room temperature and washed 3 times with TNT buffer. The samples were counter-stained with DAPI $\left(1 \mu \mathrm{g} \mathrm{ml}^{-1}\right)$ for $5 \mathrm{~min}$ and washed with PBS. The anti-fading solution and cover glasses were mounted on the slides. The slides were examined by using an Olympus BH51 epifluorescence microscope equipped with a UPlanApo $100 \times$ objective (total magnification $\times 1000$ ).

Permeabilization and denaturation tests. To optimize the accessibility of the antibody to the incorporated BrdU, we examined the effects of incubation time with enzymes employed in permeabilization and denaturation on the signal strength of immunocytochemical detection. The marine Vibrio isolate SB5 labeled with BrdU by the method described above was used as a test species, because in our preliminary test Vibrio isolates appeared to have the least permeable cell wall and membrane among the Gram-negative isolates tested in this study (see 'Discussion' for details). All treatments, except the incubation time specified in Table 2, were performed using the same conditions as described above. The Vibrio isolate SB5 cells cultured with $200 \mathrm{nM}$ TdR were used as negative controls to check for non-specific signals.

Detection limit of BrdU immunocytochemistry for bacterial cells. In order to obtain bacterial cells with different levels of incorporated BrdU, the marine Vibrio SB5 was grown in SWM medium with $100 \mathrm{nM}$ BrdU or ${ }^{3} \mathrm{H}-\mathrm{BrdU}$ (Moravek Biochemicals) and subsampled at multiple time points. The overnight culture was inoculated into 5 replicate polystyrene snap-cap tubes and incubated at $18^{\circ} \mathrm{C}$. One tube contained nonradioactive BrdU and was used for immunocytochemical detection. The other 4 replicate tubes contained ${ }^{3} \mathrm{H}-\mathrm{BrdU}$ and were used to determine cell specific BrdU incorporation. Prior to the inoculation of bacteria, 1 of 4 tubes received $5 \%$ final trichloroacetic acid (TCA) to kill the bacteria and use it as a negative control. The subsampling was conducted at 2, 10, 20,60, $120,180 \mathrm{~min}$ of the first incubation and at 30,60, 120, $180,240,300,360 \mathrm{~min}$ of the second incubation. Incorporation of ${ }^{3} \mathrm{H}-\mathrm{BrdU}$ was measured according to the microcentrifugation protocol of Smith \& Azam (1992), while the non-radioactive BrdU samples were processed as above for immunocytochemical detection.

Relationship between growth rate and cell-specific signal intensity. Five marine isolates (Km1, D8, G22, D21, F3) identified as members of the CFB group were grown in SWM medium at room temperature for $2 \mathrm{~d}$. An aliquot of each culture was inoculated into a fresh SWM medium to obtain an $\mathrm{OD}_{600}$ in the range of 0.01 to 0.02 . After incubation at $22^{\circ} \mathrm{C}$ for $2 \mathrm{~h}$, the experimental tubes $(10 \mathrm{ml})$ were supplemented with $\operatorname{BrdU}$ at $10 \mu \mathrm{M}$ final concentration. The duplicate cultures were further incubated for $5 \mathrm{~h}$. Subsamples $(0.5 \mathrm{ml})$ were withdrawn for growth rate measurements at the $0,2,5$, and $7 \mathrm{~h}$ during a total $7 \mathrm{~h}$ incubation. Samples were kept in the dark during incubations. The subsamples were fixed with $4 \%$ formaldehyde and kept cool and dark until analysis. At the end of the incubation, the duplicate samples were pooled in one batch and pelleted by centrifugation at $20000 \times g$ for $5 \mathrm{~min}$. The pelleted cells were processed for immunocytochemical detection of BrdU as described above. Cell-specific fluorescence intensity was measured by capturing an epifluorescent micrograph with a monochrome CoolSNAP HQCCD camera (Roper Scientific). The image was analyzed with MetaMorph Imaging System Software (Universal Imaging). The software automatically recognized cell-like particles based on brightness distributions. We set thresholds to determine the cell margins and to eliminate too small and too large particles, comparing the captured image with the real image under the microscope. Also, particles recognized as having irregular and obviously non-bacterial shapes were manually eliminated. Background signals were not subtracted, because they were consistently very low and had little effect on signal variability. The integrated gray value of each cell was measured to use it as an indicator of cellular fluorescence intensity. An averaged gray value of 200 to 1000 cells was obtained for each isolate. Concurrently, the increase in cell numbers was monitored by direct count using fluores- 
cence microscopy following DAPI staining. The growth rate of each strain was estimated from linear regression at 2, 5 and $7 \mathrm{~h}$ during the incubation.

BrdU incorporation into bacterial cells in natural seawater. Coastal surface seawater was collected with a weighted polycarbonate flask from the end of the pier at Scripps Institution of Oceanography on 5 October 2001, and used for the following experiments within $1 \mathrm{~h}$ of collection. Aliquots of the seawater were incubated with various concentrations of BrdU (10 nM, $100 \mathrm{nM}$, $1 \mu \mathrm{M}$ and $10 \mu \mathrm{M})$ in the dark at in situ temperature $(20 \pm$ $2{ }^{\circ} \mathrm{C}$ ), subsampled and fixed with $4 \%$ formaldehyde at 5 time-points for up to $5 \mathrm{~h}$. Controls were incubated with TdR instead of BrdU at each concentration and fixed at the end of the incubations. Fixed samples were filtered onto $0.2 \mu \mathrm{m}$ pore-size polycarbonate black filters (25 mm diameter, Osmonics) and cut into 4 pieces. To transfer the materials trapped on the filters to glass slides, each piece was placed upside down onto a 6 mm-diameter well of the Teflon printed glass slides and the filter was gently peeled off. Prior to transfer, the wells of the glass slide were coated with poly-L-lysine (Sigma) by placing $0.01 \%(\mathrm{w} / \mathrm{v})$ solution in each well, removing excess solutions with a pipette and letting the slides air-dry. Then, all the slides were processed for immunocytochemical detection of BrdU from ethanol dehydration as described above. The slides were counter-stained with DAPI, and the number of BrdU positive cells and total number of cells were counted.
BrdU incorporation into bacterial cells in detritusenriched seawater. Coastal seawater was collected as described above at the pier of Scripps Institution of Oceanography on 14 January 2002. The seawater was incubated with $1 \mu \mathrm{M}$ BrdU in a $50 \mathrm{ml}$ plastic tube in the dark at in situ temperature $\left(15 \pm 2{ }^{\circ} \mathrm{C}\right)$. The tube was enriched with freeze-thaw killed Thalassiosira weissflogii cells (5000 cells $\mathrm{ml}^{-1}$ ) prepared as previously described in Bidle \& Azam (2001). Subsamples were taken and fixed with $4 \%$ formaldehyde at 7 timepoints for up to $48 \mathrm{~h}$, and processed for immunocytochemical detection of BrdU as described above. The number of BrdU-positive and DAPI-stained cells, as well as the number of free and attached cells, were counted. Colored fluorescence images were captured by the CoolSNAP HQ CCD camera equipped with a tunable RGB filter (Cambridge Research \& Instrumentation).

\section{RESULTS}

\section{BrdU immnocytochemical detection}

Immunocytochemical detection of incorporated BrdU showed positive signals for all isolates (Table 1). No signals were detected from cells of any isolate incubated with TdR instead of BrdU. The signals of 2 isolates, SB12 and S-10, while distinguishable from those

Table 1. Immunocytochemical detection of 5-bromo-2'-deoxyuridine (BrdU) incorporated by marine bacterial isolates. Isolate B19 was identified by colony hybridization using a group-specific oligonucleotide probe, but its 16S rRNA sequence has not been confirmed yet (L. B. Fandino pers. comm.). +: BrdU detected; -: not detected

\begin{tabular}{|c|c|c|c|c|}
\hline $\begin{array}{l}\text { Phylogenetic grouping } \\
\text { and genus of closest relatives }\end{array}$ & $\begin{array}{l}\text { Isolate } \\
\text { name }\end{array}$ & $\begin{array}{c}\text { GenBank } \\
\text { accession no. }\end{array}$ & $\begin{array}{l}\text { BrdU antibody } \\
\text { detection }\end{array}$ & Source \\
\hline \multicolumn{5}{|l|}{$\gamma$-proteobacteria } \\
\hline Pseudoalteromonas & BBFL4 & AF366032 & + & Long \& Azam (2001b) \\
\hline Pseudoalteromonas & BB2FL1 & AF366031 & + & Long \& Azam (2001b) \\
\hline Pseudoalteromonas & JSL12-2 & AF366034 & + & Long \& Azam (2001b) \\
\hline Vibrio & SB5 & AF366019 & + & Long \& Azam (2001b) \\
\hline Vibrio & SB7 & AF366020 & + & Long \& Azam (2001b) \\
\hline \multicolumn{5}{|l|}{$\alpha$-proteobacteria } \\
\hline Roseobacter & BBAT1 & AF365992 & + & Long \& Azam (2001b) \\
\hline Roseobacter & BBAT3 & AF365994 & + & Long \& Azam (2001b) \\
\hline \multicolumn{5}{|c|}{ Cytophaga-Flavobacterium-Bacteroides } \\
\hline Flexibacter & SB12 & AF366002 & $+/-$ & Long \& Azam (2001b) \\
\hline Flexibacter & $\mathrm{Km} 1$ & AF367847 & + & Unpublished \\
\hline Flexibacter & D8 & AF125323 & + & Fandino et al. (2001) \\
\hline Flexibacter & D21 & AY030100 & + & Unpublished \\
\hline Cytophaga & F3 & AF125326 & + & Fandino et al. (2001) \\
\hline \multirow{2}{*}{ Cytophaga } & G22 & AF125324 & + & Fandino et al. (2001) \\
\hline & B19 & & + & Fandino pers. comm. \\
\hline \multicolumn{5}{|l|}{ Gram-positive bacteria } \\
\hline Staphylococcus & S-10 & AF488783 & $+/-$ & Long \& Azam (2001b) \\
\hline
\end{tabular}


Table 2. Fluorescence signal intensity of the marine isolate SB5 by 5-bromo-2'-deoxyuridine (BrdU) immunocytochemistry with various cell treatments. Signal intensity level is indicated by the number of plus symbols: $+++>++>+$. -: no signal

\begin{tabular}{|lcc|}
\hline Treatment (min) & BrdU & Control \\
\hline Permeabilization & & \\
Pepsin $\left(2 \mathrm{mg} \mathrm{ml}^{-1}, 37^{\circ} \mathrm{C}\right)$ & & \\
0 & - & - \\
10 & + & - \\
30 & + & - \\
60 & + & - \\
90 & +++ & - \\
120 & +++ & - \\
150 & ++ & + \\
180 & ++ & - \\
Lysozyme $\left(3 \mathrm{mg} \mathrm{ml}^{-1}\right.$, room temp.) & & \\
0 & ++ & - \\
30 & +++ & - \\
45 & +++ & - \\
75 & + & - \\
Denaturation & & \\
Nuclease $\left(37^{\circ} \mathrm{C}\right)$ & & - \\
0 & + & - \\
60 & ++ & - \\
120 & +++ & - \\
Overnight $\left(4^{\circ} \mathrm{C}\right)$ & + & - \\
& & \\
\hline
\end{tabular}

of controls, however were weaker than those of other isolates. Growth rates ranged $0.01-0.61 \mathrm{~h}^{-1}$ during incubation for BrdU labeling.

\section{Permeabilization and denaturation}

Optimum incubation durations to achieve a strong immunocytochemical signal were selected on the basis of the result of permeabilization and a denaturation test using SB5 (Table 2). A signal was obtained without lysozyme treatment, although the intensity was weaker than for the treated samples, while pepsin and nuclease treatments were essential. Treatment for 60 and 90 min with pepsin, 30 and 45 min with lysozyme, and $2 \mathrm{~h}$ with nuclease gave the strongest signals.

\section{Detection limit}

Detection limit of immunocytochemical staining was also determined using SB5. The cellular BrdU content was estimated from ${ }^{3} \mathrm{H}$-BrdU incorporation. It increased over time and reached $0.080 \pm 0.0067 \mathrm{amol}$ $\mathrm{cell}^{-1}$ in the first incubation, however, the signal of immunocytochemical detection of BrdU could not be observed from all of these samples. In the second incuba- tion, fresh media was added to accelerate the growth of SB5 and thus BrdU incorporation. The cellular BrdU content was $0.37 \pm 0.06 \mathrm{amol} \mathrm{cell}^{-1}$ at $30 \mathrm{~min}$, increasing to $0.60 \mathrm{amol} \mathrm{cell}^{-1}$ (an average of duplicate data: the values for 3 replicates were $0.09,0.59$ and 0.62 and we omitted 0.09 in the average) at $60 \mathrm{~min}$, which then decreased over time $(120,180,240,300 \mathrm{~min})$ probably due to the dilution of BrdU incorporated into the cells, and reached $0.073 \pm 0.024 \mathrm{amol} \mathrm{cell}^{-1}$ at the end of the incubation (360 min). The cells outpaced the availability of exogenous BrdU in the middle of growth and thus, when exogenous BrdU was depleted but the cells were still growing, $\mathrm{BrdU}$ in the cells would have been diluted by successive cell division. The signal of BrdU immunocytochemistry was detectable for all of these samples. The amounts of BrdU incorporated into a cell and our detection ability are summarized in Fig. 1. The amounts of BrdU incorporated ranged from $0.0002 \pm$ 0.0001 to $0.42 \pm 0.027 \mathrm{amol} \mathrm{cell}^{-1}$. Below $0.1 \mathrm{amol} \mathrm{BrdU}$ cell $^{-1}$, a reliable limit could not be determined as cells at $0.073 \pm 0.024 \mathrm{amol} \mathrm{BrdU}$ cell $^{-1}$ were detectable, while the cells with $0.080 \pm 0.0067 \mathrm{amol} \mathrm{BrdU}$ cell $^{-1}$ were not. However, samples at greater than $0.1 \mathrm{amol}$ BrdU cell ${ }^{-1}$ were all detectable.

\section{Growth rates and fluorescence signal intensity}

Five CFB isolates showed specific growth rates ranging from 0.015 to $0.037 \mathrm{~h}^{-1}$ (Fig. 2). Cell-specific fluorescence signal intensity of the BrdU immunoassay was significantly correlated with specific growth rates of the isolates $(\mathrm{r}=0.940, \mathrm{p}<0.01)$.

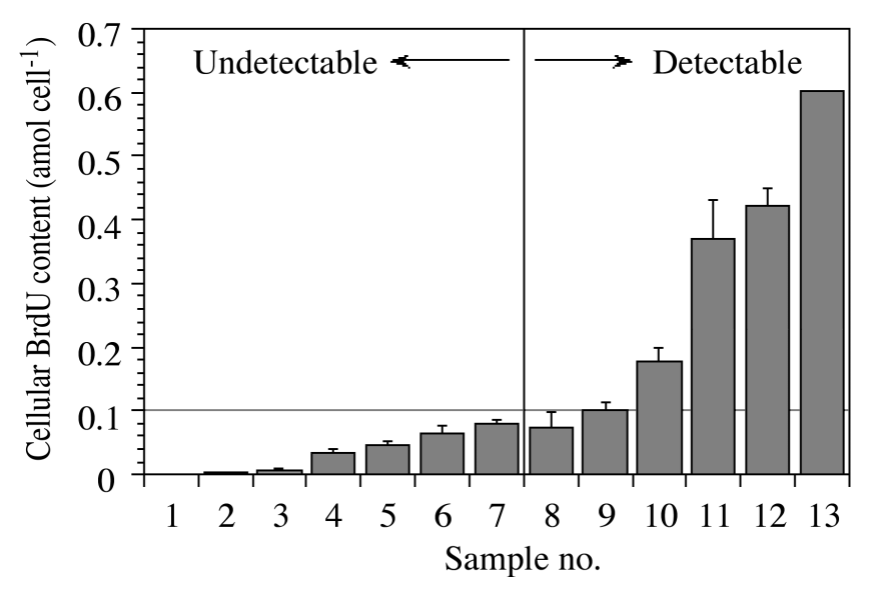

Fig. 1. Detection limits of cellular BrdU content of Vibrio isolate SB5 by immunocytochemical staining. Time-course samples were taken from parallel incubations with 1 set of 5 -bromo-2'-deoxyuridine (BrdU) and 3 sets of ${ }^{3} \mathrm{H}$-BrdU. Cellular BrdU content was derived from ${ }^{3} \mathrm{H}$-BrdU incorporation.

Error bar shows \pm 1 SD except Sample 13, where $n=2$ 


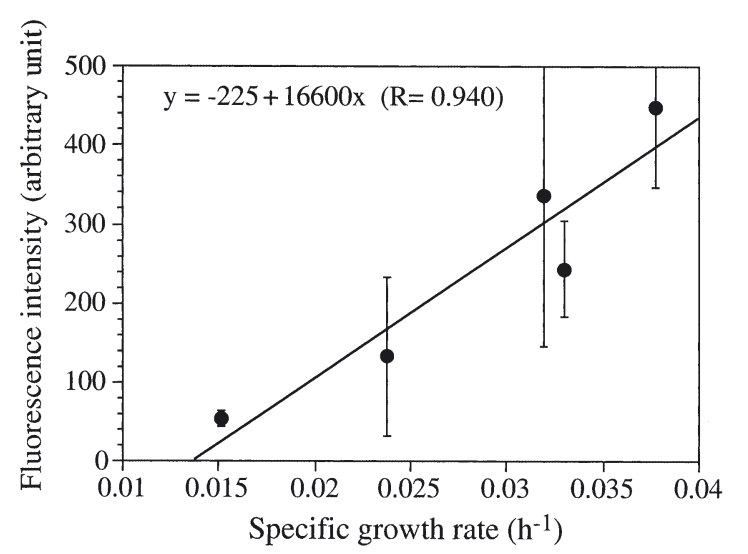

Fig. 2. Relationship between the specific growth rates of $C y$ tophaga-Flavobacter-Bacteroides (CFB) group isolates and cell specific fluorescence intensity as a proxy of BrdU incorporation. Error bars show $\pm 1 \mathrm{SD}$. Growth rates are mean values of duplicate measurements. Error bar indicates the deviation of fluorescence intensity among 200 to 1000 cells

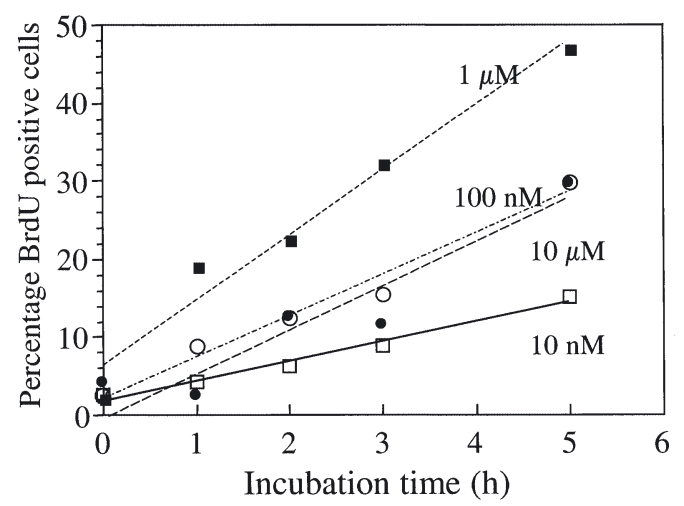

Fig. 3. 5-bromo-2'-deoxyuridine (BrdU) positive cells during an incubation of coastal seawater at different concentrations of BrdU. Data are mean values of duplicate measurements. Regression equations derived by the least square method are $y=2.52 x+1.87$ for $10 \mathrm{nM} \operatorname{BrdU}(\square), y=5.22 x+2.38$ for $100 \mathrm{nM} \operatorname{BrdU}(0), y=8.46 x+6.05$ for $1 \mu \mathrm{M} \operatorname{BrdU}(\boldsymbol{\square})$, and $y$ $=5.58 x-0.502$ for $10 \mu \mathrm{M} \operatorname{BrdU}(\bullet)$. The multiple correlation coefficient, $\mathrm{R}$, is $0.983,0.968,0.967$ and 0.916 , respectively. SD of each slope is $0.269,0.765,1.27$ and 1.29, respectively

\section{Incorporation by bacteria in natural seawater samples}

BrdU incorporation for seawater samples showed an increase of BrdU-positive cells over time (Fig. 3). Positive signals were detected after $1 \mathrm{~h}$ incubation with BrdU. The highest BrdU concentration did not give the highest percentage of positive signals, and the appropriate BrdU concentration to maximize the percentage of BrdU positive cells was $1 \mu \mathrm{M}$ in natural seawater (Fig. 3). The percentage of BrdU-positive cells from the total number of cells increased to up to $47 \%$. The false

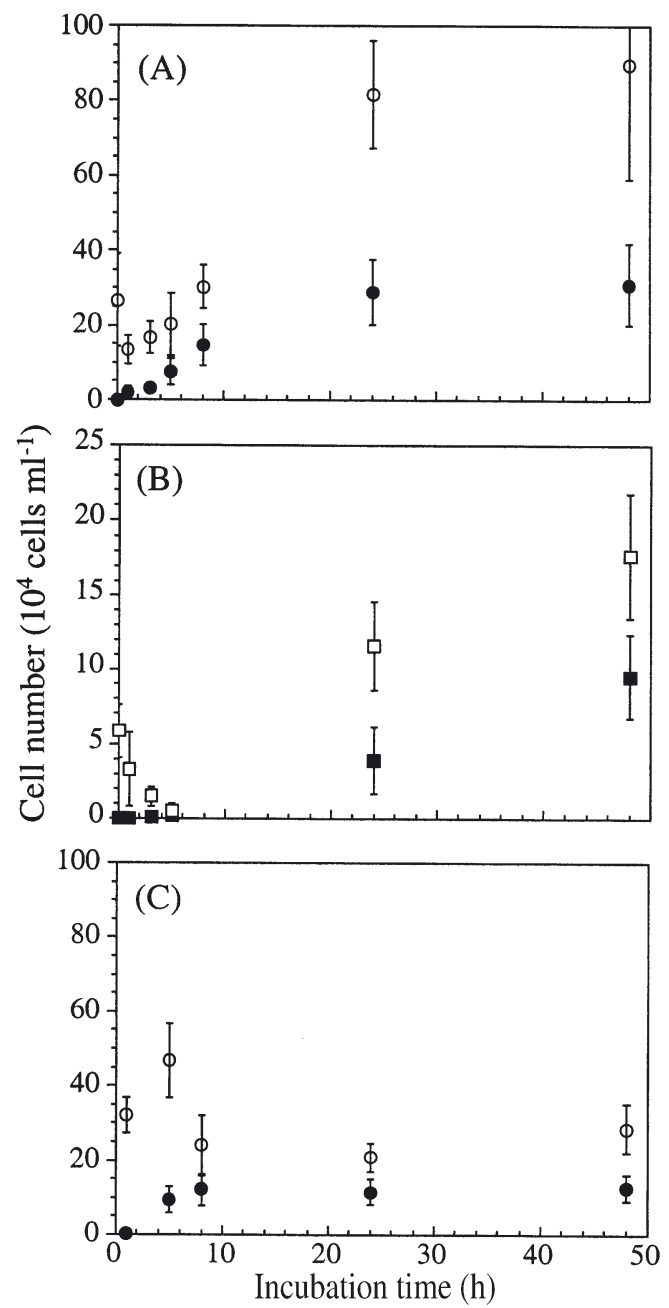

Fig. 4. Effects of phytoplankton-detritus enrichment on individual cell growth. Time course of the number of total bacteria $(\mathrm{O}, \square)$ and $\operatorname{BrdU}$ positive bacteria $(\bullet, \mathbf{\square})$ during an incubation of coastal seawater with $1 \mu \mathrm{M}$ 5-bromo-2'deoxyuridine (BrdU) and freeze-thaw-killed diatoms detritus enrichment. (A) Free-living bacteria. (B) Particleattached bacteria in the enriched seawater microcosm. (C) Free-living bacteria in seawater without detritus enrichment. Error bars show $\pm 1 \mathrm{SD}$

positive signals observed in TdR control samples were less than $5 \%$. The percentage of positive cells varied with different concentrations of BrdU. Coating a glass slide with poly-L-lysine resulted in a highly effective transfer of cells from the filter. In our preliminary experiment, cell counts on glass slides after the transfer did not show statistically significant differences in comparison with cell counts on filters. Also, cells remaining on the filter after the transfer were too scarce to have enough counts $(<1$ per microscope fieldof-view). Further treatment with ethanol and pepsin did not significantly affect the retention of transferred cells on the glass slide. 


\section{BrdU incorporation in detritus-enriched seawater samples}

The total number of cells increased in the enriched seawater, whereas this was not observed in the seawater without enrichment. BrdU-positive cells were detectable after $1 \mathrm{~h}$ of incubation in both of the seawater cultures, and increased for $24 \mathrm{~h}$ in the enriched seawater and for $8 \mathrm{~h}$ in the seawater without enrichment (Fig. 4A,C). Significant attachment of bacteria to particles was observed after $24 \mathrm{~h}$ incubation (Fig. $4 \mathrm{~B}$ ). Actively growing cells on detritus were successfully visualized (Fig. 5). The percentage of BrdU-positive cells reached $35 \%$ for free-living cells (Fig. 4A) and $56 \%$ for particle-attached cells (Fig. 4B) in the enriched microcosm and $45 \%$ for free-living cells in the unenriched one (Fig. 4C).

\section{DISCUSSION}

Assemblage-level studies of heterotrophic bacterial production during the last 2 decades have had a major influence on our concepts of pelagic food webs and oceanic carbon cycling. They have also raised new questions on mechanisms that underlie the ability of bacteria to interact with organic matter and thus compete with particle-eating organisms and other bacteria. In order to address such questions we need to develop a set of methods and a conceptual framework to explore individual cell-based ecology and biogeochemical activities of pelagic bacteria at the microscale. Pioneering work by Overney \& Fuhrman (1999), Lee et al. (1999) and Cottrell \& Kirchman $(2000 a, b)$ has resulted in methods that combine microautoradiography and fluorescent in situ hybridization (FISH) to assess individual cell-based rates of metabolism and growth. Our method should complement these methods by obviating the use of radioisotopes as well as offering some additional capabilities. We demonstrate the feasibility, potential and limitations in using the method in field studies as well as discuss avenues to improve its capabilities.

The desirability of a non-radioisotopic method is selfevident to the field ecologist. As a basis for measuring bacterial growth rate, BrdU may also offer some additional advantages over the ${ }^{3} \mathrm{H}-\mathrm{TdR}$, as discussed by Steward \& Azam (1999) in relation to their assemblage-level BrdU-based method. BrdU provides greater specificity of incorporation into DNA and of detection by the antibody (the antibody is not expected to detect any brominated molecules produced by potential metabolism of BrdU). An advantage of BrdU over microautoradiography for individual cell-growth studies is that the fluorescence signal of even closely

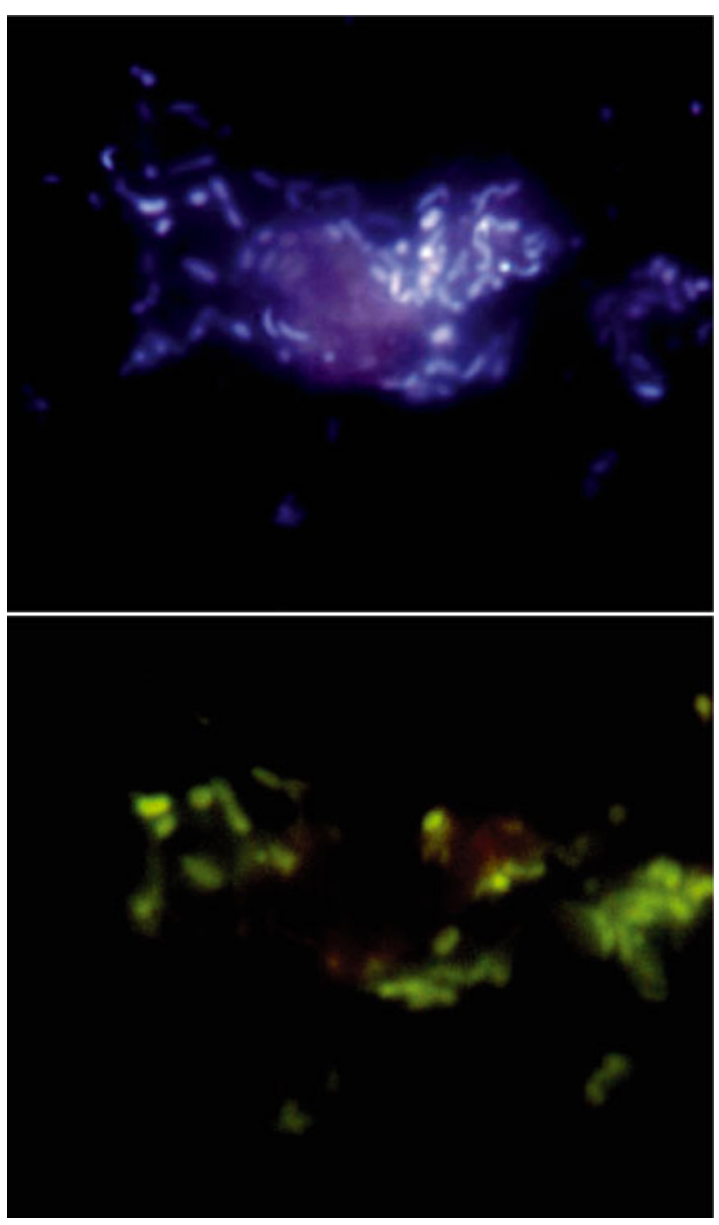

Fig. 5. Epifluorescence photomicrograph of natural bacterial assemblages attached to diatom detritus. Bacteria incubated with 5-bromo-2'-deoxyuridine (BrdU) were double stained with immunocytochemistry using anti-BrdU antibody and DAPI. Under UV light excitation, all bacteria stained by DAPI show bluish-white fluorescence and a diatom cell shows reddish fluorescence due to photosynthetic pigments (upper). Actively growing bacteria are selectively labeled with BrdU and show green fluorescence under blue light excitation (lower)

located individual cells, e.g. those colonizing a particle, can generally be discriminated. Indeed, the BrdU approach should enable growth studies, by confocal microscopy, of bacteria on marine particles or in biofilms. Thus, the method may be particularly useful in testing hypotheses on microspatial growth patterns and responses.

Not all bacteria incorporate ${ }^{3} \mathrm{H}$-thymidine but early microautoradiography studies (Fuhrman \& Azam 1982) showed that non-responsive bacteria comprised a minor fraction of bacterial assemblages in seawater. They may fail to incorporate ${ }^{3} \mathrm{H}$-thymidine into DNA during growth possibly for lack of transmembrane transport systems or thymidine kinase (Pollard \& Mori- 
arty 1984, Jeffrey \& Paul 1990). Likewise, a small fraction of growing bacteria in seawater may fail to incorporate BrdU. Urbach et al. (1999) could not detect DNA labeling with BrdU in 2 marine isolates (a Flavobacterium sp. and a Gram-positive bacterium) by dot-blot analysis of extracted DNA out of 4 tested isolates. Pernthaler et al. (2002) showed that $\alpha$-proteobacteria, CFB-group bacteria and Actinobacteria all had the ability to incorporate BrdU. We found that BrdU is incorporated by isolates belonging to all major taxonomic groups of marine bacteria, including $\gamma$-proteobacteria, $\alpha$-proteobacteria, CFB-group bacteria and Gram-positive bacteria. These groups comprise the dominant fraction of coastal marine bacteria in pelagic environments (e.g. Suzuki et al. 1997, Cottrell \& Kirchman 2000a, Fandino et al. 2001). Recently, microautoradiography combined with FISH showed that major groups of marine bacteria appeared to incorporate ${ }^{3} \mathrm{H}$ thymidine (Cottrell \& Kirchman 2003). While the possible presence of BrdU-non-responsive cells should be kept in mind, our results suggest that the BrdU approach has the potential to be broadly applicable to all major phylogenetic groups of bacteria in pelagic marine assemblages.

A critical issue for the feasibility of individual-cell BrdU detection was to optimize the sample treatment protocol in order to maximize the penetration of antibody-enzyme conjugate into the cells, while preventing DNA egress. Lanoil \& Giovannoni (1997) employed pepsin and lysozyme treatments for large DNA probes to permeate the cell membrane in bacterial chromosomal painting. Urbach et al. (1999) successfully applied this protocol to immunocytochemical detection of BrdU-labeled Roseobacter sp. and Alteromonas sp. In our study, the results of treatments with these digestive enzymes varied among different bacterial species tested. For instance, pepsin treatment was essential for Roseobactor and Vibrio isolates but not for Pseudoalteromonas isolates. Further, the Roseobactor BBAT1 required pepsin treatment for a shorter time than the Vibrio SB5. Given such variability, we decided to use SB5, our 'hardiest' Gram-negative isolate, as the model in optimizing the treatment conditions for natural assemblages. Pernthaler et al. (2002) used a warmed surfactant (Triton X-100) and lysozyme to permeabilize cells for FISH and BrdU detection. The method was applicable to 21 strains of bacterial isolates belonging to $\alpha$-proteobacteria, CFB-group bacteria and Actinobacteria, although 1 of 2 strains of Actinobacteria showed a low percentage of positive signals. Their treatment for permeabilization requires less incubation time than ours and thus may be useful to shorten the processing time. Gram-positive bacteria are expected to require a harsher treatment to achieve antibody-enzyme conjugate penetration than Gram- negative bacteria (Schonhuber et al. 1997). We focused more on testing Gram-nagative bacteria because they presumably dominate the coastal pelagic waters. Protocols for Gram-positive bacteria should be further evaluated in future works.

In preliminary experiments, we tried centrifugation to collect bacterial cells in natural seawaters. The recovery efficiency of bacterial cells was $63 \pm 9.4 \%$ during the process for concentration by centrifugation. The filter transfer protocol, in contrast, showed no significant cell loss. Filtration rather than centrifugation also preserves some microspatial information on individual cells (e.g. growth rates of attached and 'free' bacteria). We also sought to simplify the protocol by performing the entire sample processing on the filter (without transfer to a slide), but this required larger reagent volumes as well as increasing the background fluorescence due to non-specific binding of antibody and fluorochromes to the filter. Transferring the filtered cells to a glass slide yields better results for seawater samples.

The highest percentage of the BrdU positive signal was obtained at $1 \mu \mathrm{M}$ BrdU in the seawater incubation experiment (Fig. 3). The percentage positive signal at $10 \mu \mathrm{M}$ BrdU was less than that at $1 \mu \mathrm{M}$, indicating some inhibition in BrdU incorporation or DNA synthesis at high BrdU concentration. One possible explanation is that mutagenic or other genotoxic effects of BrdU prevented further incorporation or DNA synthesis (Hanawalt 1967, Binnie \& Coote 1986, Yamamoto \& Fujiwara 1990). The thymidine analog, BrdU, can be easily incorporated into DNA in place of the natural base probably because of a similar van der Waals radius of the bromine atom to the methyl group at the 5-carbon position of the pyrimidine ring. However, 5bromouracil in DNA may pair with guanine instead of adenine, because the bromine atom has greater electronegativity than the methyl group. This may change electron distribution in the pyrimidine ring and thus may cause a shift in chemical structure from keto to enol state. This keto-enol shift is thought to be responsible for the mutagenic effect of 5-bromourracil in DNA. A strain of Escherichia coli incorporates 5-bromouracil but eventually stops DNA synthesis at a concentration of ca. $50 \mu \mathrm{M}$ (Hanawalt 1967). Binne \& Coote (1986) showed that BrdU altered the normal pattern of DNA synthesis of a strain of Bacillus subtilis, and caused inhibitory effects on sporulation. Also, bacterial DNA labeled with BrdU becomes susceptible to inactivation by UV or visible light (Yamamoto \& Fujiwara 1990).

The appropriate BrdU concentration to maximize percentage BrdU positive cells was $1 \mu \mathrm{M}$ in natural seawater (Fig. 3). However, this is 100 -fold higher than that of ${ }^{3} \mathrm{H}$-TdR routinely used in radiotracer studies, 
and also that of BrdU reported to show saturation in seawater incubation by Steward \& Azam (1999). By adding a high concentration of BrdU, a stimulation of growth due to the metabolism of $\mathrm{BrdU}$ as a nutrient source might become significant, which possibly leads to overestimation of in situ active cells. As BrdU contains 9 molecules of carbon, $1 \mu \mathrm{M}$ of BrdU is comparable to $9 \mu \mathrm{M}$ of carbon concentration. If the DOC concentration of seawater is $\sim 90 \mu \mathrm{M}$, a typical value found in coastal area, and contains 10 to $20 \%$ labile fraction, addition of $\mathrm{BrdU}$ in $1 \mu \mathrm{M}$ of final concentration causes roughly a 50 to $100 \%$ increase of available organic carbon content in the seawater. Although a significant increase of bacterial cell abundance was not observed in our seawater cultures, a possibility that BrdU served as a 'nutrient' rather than a tracer could not be ruled out. Further works examining changes of community structure should evaluate whether adding $1 \mu \mathrm{M}$ BrdU specifically stimulates the growth of some bacteria but not others.

The sensitivity of detecting BrdU incorporation in individually growing bacteria should increase with the length of incubation with BrdU. However, shorter incubations are generally desirable in testing hypotheses on in situ bacterial growth; longer containment periods could influence the growth rates being measured, due to the container 'wall effect', grazing, viral lysis, or substrate depletion. Thus, most studies of assemblagelevel growth measurements incubate 2 to $10 \mathrm{ml}$ seawater samples for a few hours (Smith \& Azam 1992, Kemp et al. 1993, Biddanda et al. 1994, Pakulski et al. 1998, Steward \& Azam 1999), as we did here. Our detection limit for BrdU incorporation was $\sim 0.1 \mathrm{amol} \mathrm{cell}^{-1}$ for SB5 (Fig. 1), while a pelagic bacterium is estimated to incorporate $0.5 \mathrm{amol} \mathrm{cell}^{-1} \mathrm{BrdU}$ to double its DNA (we assume $0.7 \mathrm{amol} \mathrm{cell}^{-1} \mathrm{TdR}$ per doubling [Fuhrman \& Azam 1982] and a BrdU:TdR incorporation ratio of 0.7 [Steward \& Azam 1999]). Thus, $5 \mathrm{~h}$ incubations would suffice for a bacterium doubling its DNA in $25 \mathrm{~h}$ to incorporate sufficient $\mathrm{BrdU}(0.1 \mathrm{amol})$ to become detectable. Therefore, using our current protocol, longer incubations would be required to detect any growth of bacteria with doubling times greater than $\sim 1 \mathrm{~d}\left(0.028 \mathrm{~h}^{-1}\right.$ for growth rate). If slow-growing assemblages are being studied, we suggest using large seawater samples to minimize containment effects. Since BrdU is inexpensive and non-radioactive, it should even be practical to use sample sizes of many liters during incubation (followed by processing of small aliquots). We caution, however, that $\mathrm{BrdU}$ is mutagenic and appropriate protocols should be developed for disposing large volumes, e.g. after volume reduction by adsorption to a suitable matrix.

The method sensitivity appears sufficient to gain useful insights and constraints on bacterial growth in seawater samples. Our eventual goal is to quantify individual cell fluorescence and rigorously calibrate it against standard curves to directly compute individual cell growth rate. This goal is feasible, if we have more uniform signals and evaluate species variability of the relationship (Fig. 2). Further, we quantified the time taken by a fraction of the bacterial assemblage to equal or exceed the BrdU incorporation of $0.1 \mathrm{amol}$, our detection limit based on culture studies. A substantial fraction, $19 \%$, of an assemblage off Scripps Pier became BrdU-positive in only $1 \mathrm{~h}$ incubation (Fig. 3). These cells would therefore be growing at $0.14 \mathrm{~h}^{-1}$ (doubling time $5 \mathrm{~h}$ ) or faster (assuming that detection threshold of SB5 is applicable to natural assemblages of bacteria). These measurements, although quite limited, lead to the interesting conclusion that the nutrient status of coastal seawater samples examined by us was conducive to rapid growth of a significant fraction of the bacterial assemblages. A larger fraction $(47 \%$ at $5 \mathrm{~h}$ ) became BrdU-positive with an increase in incubation time. Longer incubation times or otherwise enhanced sensitivity may be required in environments such as oligotrophic regions or the deep sea where bacterial growth is expected to be very slow. However, the method in its present level of sensitivity can be used to test whether the environments exhibiting very low assemblage-average growth rates contain hotspots of relatively fast growth.

The response of the natural assemblage to enrichment with detritus particles was observed with our method. Free-living bacteria showed rapid growth enhancement; $15 \%$ of the cells were scored positive within $1 \mathrm{~h}$ (Fig. 4). Attachment of bacteria to particles was observed within $1 \mathrm{~h}$ of incubation, and $31 \%$ of the attached cells were scored positive within $24 \mathrm{~h}$ (Fig. 4). Also, large and comparable fractions of both free living $(65 \%)$ and attached $(46 \%)$ bacteria remained BrdUnegative even after $48 \mathrm{~h}$ incubation, suggesting that they were growing very slowly ( $>10 \mathrm{~d}$ doubling time), were dormant or non-responsive to our BrdU protocol. These observations also suggest that the BrdU method in conjunction with nutrient and other perturbation is potentially applicable to testing hypotheses on environmental factors affecting the growth physiology and ecology of bacteria in natural marine assemblages.

The potential of the BrdU method to preserve microspatial growth information, e.g. growth of bacteria associated with particles or other organisms, is a strong motivation to further develop the methodology. Microspatial structure of the organic matter field and bacterial interactions with it are important in understanding bacterial ecology and organic matter dynamics in the ocean (Azam 1998, Azam \& Long 2001, Long \& Azam 2001a). Our study shows that the approach has promise. We could successfully visualize bacterial cells 
that were growing on phytoplankton detritus (Fig. 5). Also, the linear relationship between growth rate and fluorescence intensity suggested the possibility for direct quantitative analysis of bacterial growth at the single-cell level (Fig. 2). Combining BrdU and FISH or fluorescence antibody methods should help determine species-specific in situ growth rates at the individualcell level (Pernthaler et al. 2002). In sum, the BrdU approach can contribute to the development of individual cell-based ecology of marine bacteria and understand how microscale interactions of bacteria regulate ocean-basin scale biogeochemistry.

Acknowledgements. We thank Laura B. Fandino and Lasse Riemann for providing Cytophaga isolates, Grieg F. Steward for providing useful advice when beginning this work, and 3 anonymous reviewers for comments to improve the manuscript. This research was supported by NIH (NIAID) Grant A146600 to F.A., and Postdoctoral Fellowships for Research Abroad, Grant-in-Aid for Exploratory Research (No. 14656077, 14656129), Grant-in-Aid for Young Scientist (No. 15688006) from The Japan Society for the Promotion of Science to K.H.

\section{LITERATURE CITED}

Asquith B, Debecq C, Macallan DC, Willems L, Bangham CRM (2002) Lymphocyte kinetics: the interpretation of labeling data. Trends Immunol 23:596-601

Azam F (1998) Microbial control of oceanic carbon flux: the plot thickens. Science 280:694-696

Azam F, Long RA (2001) Sea snow microcosms. Nature 414: 495-498

Biddanda B, Opsahl S, Benner R (1994) Plankton respiration and carbon flux through bacterioplankton on the Louisiana shelf. Limnol Oceanogr 39:1259-1275

Bidle KD, Azam F (1999) Accelerated dissolution of diatom silica by marine bacterial assemblages. Nature 397:508-512

Bidle KD, Azam F (2001) Bacterial control of silicon regeneration from diatom detritus: significance of bacterial ectohydrolases and species identity. Limnol Oceanogr 46: 1606-1623

Binnie C, Coote JG (1986) Inhibition of sporulation in Bacillus subtilis by bromodeoxyuridine and the effect on DNA replication. J Gen Microbiol 132:493-502

Borneman J (1999) Culture-independent identification of microorganisms that respond to specific stimuli. Appl Environ Microbiol 65:3398-3400

Cho BC, Azam F (1988) Major role of bacteria in biogeochemical fluxes in the ocean's interior. Nature 332:441-443

Cole JJ, Findlay S, Pace ML (1988) Bacterioplankton production in fresh and saltwater ecosystems: a cross-system overview. Mar Ecol Prog Ser 43:1-10

Cottrell MT, Kirchman DL (2000a) Community composition of marine bacterioplankton determined by 16SrRNA gene clone libraries and fluorescence in situ hybridization. Appl Environ Microbiol 66:5116-5122

Cottrell MT, Kirchman DL (2000b) Natural assemblages of marine proteobacteria and members of the CytophagaFlavobacter cluster consuming low- and high-molecularweight dissolved organic matter. Appl Environ Microbiol 66:1692-1697
Cottrell MT, Kirchman DL (2003) Contribution of major bacterial groups to bacterial biomass production (thymidine and leucine incorporation) in the Delaware estuary. Limnol Oceanogr 48:168-178

DeLong EF, Taylor LT, Marsh TJ, Preston CM (1999) Visualization and enumeration of marine planktonic archaea and bacteria by using polyribonucleotide probes and fluorescent in situ hybridization. Appl Environ Microbiol 65: $5554-5563$

Dinjens WNM, ten Kate J, Lenders MHJH, van der Linden EPM, Bosman FT (1992) Bromodeoxyuridine (BrdU) immunocytochemistry by exonuclease III (Exo III) digestion. Histochemistry 98:199-205

Douglas DJ, Novitsky JA, Fournier RO (1987) Microautoradiography-based enumeration of bacteria with estimates of thymidine-specific growth and production rates. Mar Ecol Prog Ser 36:91-99

Fandino LB, Riemann L, Steward GF, Long RA, Azam F (2001) Variations in bacterial community structure during a dinoflagellate bloom analyzed by DGGE and 16SrDNA sequencing. Aquat Microb Ecol 23:119-130

Fuhrman JA, Azam F (1982) Thymidine incorporation as a measure of heterotrophic bacterioplankton production in marine surface waters: evaluation and field results. Mar Biol 66:109-120

Hanawalt PC (1967) Preparation of 5-bromouracil-labeled DNA. In: Grossman L, Moldave K (eds) Methods in enzymology. Academic Press, New York, p 702-708

Jeffrey WH, Paul JH (1990) Thymidine uptake, thymidine incorporation, and thymidine kinase activity in marine bacterium isolates. Appl Environ Microbiol 56:1367-1372

Kemp PF, Sherr B, Sherr E, Cole JJ (1993) Handbook of methods in aquatic microbial ecology. Lewis Publishers, Boca Raton, FL

Kerkhof L, Ward BB (1993) Comparison of nucleic acid hybridization and fluorometry for measurement of the relationship between RNA/DNA ratio and growth rate in a marine bacterium. Appl Environ Microbiol 59:1303-1309

Kirchman D, Williams PJB (2000) Introduction. In: Kirchman D (ed) Microbial ecology of the oceans. Wiley-Liss, New York, p 1-11

Kogure K, Simidu U, Taga N (1979) Tentative direct microscopic method for counting living marine-bacteria. Can J Microbiol 25:415-420

Lanoil BD, Giovannoni SJ (1997) Identification of bacterial cells by chromosomal painting. Appl Environ Microbiol 63:1118-1123

Lee N, Nielsen PH, Andersen KH, Juretschko S, Nielsen JL, Schleifer KH, Wagner M (1999) Combination of fluorescent in situ hybridization and microautoradiography-a new tool for structure-function analyses in microbial ecology. Appl Environ Microbiol 65:1289-1297

Long RA, Azam F (2001a) Microscale patchness of bacterioplankton assemblage richness in seawater. Aquat Microb Ecol 26:103-113

Long RA, Azam F (2001b) Antagonistic interactions among marine pelagic bacteria. Appl Environ Microbiol 67: 4975-4983

Overney CC, Fuhrman JA (1999) Combined microautoradiography-16S rRNA probe technique for determination of radioisotope uptake by specific microbial cell types in situ. Appl Environ Microbiol 65:1746-1752

Pakulski JD, Aas P, Jeffery W, Lyons M, Waasenbergen LV, Mitchell D, Coffin R (1998) Influence of light on bacterioplankton production and respiration in a subtropical coral reef. Aquat Microb Ecol 14:137-148

Pernthaler A, Penthaler J, Schattenhofer M, Amann R (2002) 
Identification of DNA-synthesizing bacterial cells in coastal North Sea plankton. Appl Environ Microb 68: 5728-5736

Pollard PC, Moriarty DJW (1984) Variability of the tritiated thymidine method for estimating bacterial growth rates: measurement of isotope dilution during DNA synthesis. Appl Environ Microb 48:1076-1083

Riemann L, Steward GF, Azam F (2000) Dynamics of bacterial community composition and activity during a mesocosm diatom bloom. Appl Environ Microbiol 66:578-587

Rodriguez GG, Phipps D, Ishiguro K, Ridgway HF (1992) Use of a fluorescent redox probe for direct visualization of actively respiring bacteria. Appl Environ Microbiol 58: 1801-1808

Schonhuber W, Fuchs B, Juretschko S, Amann R (1997) Improved sensitivity of whole-cell hybridization by the combination of horseradish peroxidase-labeled oligonucleotides and tyramide signal amplification. Appl Environ Microbiol 63:3268-3273

Smith DC, Azam F (1992) A simple, economical method for measuring bacterial protein synthesis rates in seawater using 3H-leucine. Mar Microb Food Webs 6:107-114

Steward G, Azam F (1999) Bromodeoxyuridine as an alternative to $3 \mathrm{H}$-thymidine for measuring bacterial productivity in aquatic samples. Aquat Microb Ecol 19:57-66

Editorial responsibility: Jed Fuhrman,

Los Angeles, California, USA
Suzuki MT, Rappe MS, Haimberger ZW, Winfield H, Adair N, Strobel J, Giovannoni SJ (1997) Bacterial diversity among small-subunit rRNA gene clones and cellular isolates from the same seawater sample. Appl Environ Microbiol 63: 983-989

Tsuji T, Kawasaki Y, Takeshita S, Sekiya T, Tanaka S (1995) A new fluorescence staining assay for visualizing living microorganisms in soil. Appl Environ Microbiol 61: $3415-3421$

Urbach E, Vergin KL, Giovanoni SJ (1999) Immunochemical detection and isolation of DNA from metabolically active bacteria. Appl Environ Microbiol 65:1207-1213

Van Furth R, Van Zwet TL (1988) Immunocytochemical detection of 5-bromo-2-deoxyuridine incorporation in individual cells. J Immunol Methods 108:45-51

Yamamoto Y, Fujiwara Y (1990) Uracil-DNA glycosylase cause 5-bromodeoxyuridine photosensitization in Escherichia coli K-12. J Bacteriol 172:5278-5285

Yin B, Crowley D, Sparovek G, De Melo WJ, Borneman J (2000) Bacterial functional redundancy along a soil reclamation gradient. Appl Environ Microbiol 66:4361-4365

Zimmermann R, Iturriaga R, Becker BJ (1978) Simultaneous determination of the total number of aquatic bacteria and the number thereof involved in respiration. Appl Environ Microbiol 36:926-935

Submitted: May 15, 2003; Accepted: January 23, 2004

Proofs received from author(s): April 23, 2004 